\title{
Evaluation of offspring of dairy sheep given water supplemented with crude glycerin during pregnancy and lactation ${ }^{1}$
}

\section{Avaliação das crias de ovelhas leiteiras suplementadas com glicerina bruta veiculada à agua durante a gestação e lactação}

\author{
Hemilly Cristina Menezes Sá ${ }^{*}$; Iran Borges ${ }^{2}$; Gilberto de Lima Macedo Junior ${ }^{3}$; \\ Felipe Santiago Santos ${ }^{4}$; Luigi Francis Lima Cavalcanti ${ }^{5}$; Natália Ludmila Lins Lima ${ }^{6}$; \\ Flávio Augusto Pereira Alvarenga ${ }^{6}$; Luciana Freitas Guedes ${ }^{6}$
}

\begin{abstract}
The objective of this study was to evaluate the effects of crude glycerin (CG) supplementation of dairy ewes during pregnancy and early lactation on the body weight and measurements of offspring from birth to weaning. Twenty-four lambs from 24 Lacaune x East Friesian genotype ewes were evaluated. The sheep were distributed in four treatments that differed in crude glycerin supplementation of $0 \%$, $1.5 \%, 3.0 \%$, and $4.5 \%$, as well as the concomitant adjustment of dry matter and water intake. Body measurements of lambs were recorded every two weeks from birth until weaning. Body weight was recorded daily. Multiple regression analysis revealed that supplementation with CG explained 5.2\% of the variation in the weight of lambs at birth (LW), accompanied by the body condition score of the ewe (12.3\%), sex of lamb (19.2\%), and live weight of the ewes $(26.5 \%) ; r^{2}$ was $63 \%$. According to the predictions of the model adjusted for simulated scenarios, the leanest lambs were derived from ewes weighing between 40 and $50 \mathrm{~kg}$, with body condition scores from 4 to 5 , and that did not receive CG at intermediate levels. Heavier lambs, with LW above $5.5 \mathrm{~kg}$, were derived from ewes that weighed between 80 to $90 \mathrm{~kg}$ with low body condition scores of 3, and that received $1.5 \%$ CG. Supplementation with CG between $2 \%$ and $4 \%$ improves the weight of the lambs at birth. Body measurements of lambs were not influenced by dietary supplementation of ewes with CG.
\end{abstract}

Key words: Biometrics. Byproducts. Glycerol. Ovine.

\section{Resumo}

Objetivou-se avaliar a influência da suplementação com glicerina bruta (GB) para ovelhas durante a gestação e início da lactação e seus efeitos sobre o peso e medidas corporais de suas crias do nascimento à desmama. Foram avaliados 24 cordeiros oriundos de 24 ovelhas do genótipo Lacaune $\mathrm{x}$ East Friesian distribuídas em quatro tratamentos que se diferenciaram quanto à suplementação de GB na dieta em (0;

\footnotetext{
${ }^{1}$ Prof $^{\mathrm{a}}$, Departamento de Engenharia Agronômica, Universidade Federal Sergipe, UFS, São Cristóvão, SE, Brasil. E-mail: hemilly. mg@hotmail.com

2 Prof., Universidade Federal de Minas Gerais, UFMG, Escola de Veterinária, Belo Horizonte, MG, Brasil. CNPq. E-mail: iran@ vet.ufmg.br

${ }^{3}$ Prof., Universidade Federal de Uberlândia, UFU, Uberlândia, MG, Brasil. E-mail: gilbertomacedojr@gmail.com

${ }^{4}$ M.e, Universidade Federal de Minas Gerais, UFMG, Belo Horizonte, MG, Brasil. E-mail: felipessantos@outlook.com

5 Dr. em Zootecnia, Área de concentração alimentação e nutrição animal, Escola de Veterinária, UFMG, RHAE/SEVA Engenharia, Projeto Intergado, Contagem, MG, Brasil. E-mail: luigicavalcanti22@gmail.com

${ }^{6}$ Discentes de Doutorado em Zootecnia, área de concentração alimentação e nutrição animal, Escola de Veterinária, UFMG, Belo Horizonte, MG, Brasil. E-mail: natludmila@yahoo.com.br; flaviozooalvarenga@yahoo.com.br; lucianafguedes@yahoo.com.br

* Author for correspondence
} 
1,$5 ; 3,0$ e 4,5\% de MS) sendo esta adicionada à água. As medidas biométricas dos cordeiros oriundos das mães avaliadas ocorreram quinzenalmente do dia do nascimento até o período da desmama, já o peso corporal foi avaliado diariamente. $\mathrm{O}$ estudo de regressão múltipla realizado constatou que o teor de GB na dieta das mães explicou 5,2\% da variação no peso dos cordeiros ao nascer (PN), seguidas pelo escore corporal das mães (12,3\%), sexo do cordeiro (19,2\%) e peso vivo das mães $(26,5 \%)$, totalizando $\mathrm{r}^{2}$ de $63 \%$. Segundo predições do modelo ajustado para cenários simulados, cordeiros mais leves foram oriundos de ovelhas com peso entre 40 a $50 \mathrm{~kg}$, escore 4 a 5 e que não receberam GB em níveis intermediários. Cordeiros mais pesados, com PN superior a 5,5, provinham de ovelhas pesadas, entre 80 e $90 \mathrm{~kg}$ com escore baixo e que receberam níveis de 1,5 e 3\% de GB. A suplementação com GB entre $2 \%$ e $4 \%$ melhora o peso ao nascer dos cordeiros. As medidas corporais dos cordeiros não são influenciadas pela suplementação com GB na dieta das mães.

Palavras-chave: Biometria. Glicerol. Ovinos. Subprodutos.

\section{Introduction}

Profitability in the sheep industry is directly related to the number of lambs born alive and the annual weaning rate per ewe. Several studies have found birth weight to be one of the primary determining factors in lamb survival, and consequently, profitability. In the scientific literature, this association is based on the correlation between heavy lambs and losses during birth (i.e., labor dystocia), whereas low birth weights result in lower digestive capacity, endocrine immaturity, lower muscle DNA content, and consequently, higher pre-weaning mortality (ELTAWIL et al., 1970; BRADFORD, 1972; GAMA et al., 1991; MANDAL et al., 2008). Thus, birth weight is reflective of genotypic and phenotypic factors, as well as being affected by birth type and order, lamb sex, and ewe body condition, among others.

Among the phenotypic factors, the effect of the ewes' nutritional level, especially during the final trimester of pregnancy is of importance and requires close attention because of greater fetus development during this period, leading to high nutrient demands by ewes to meet the increased energy requirements (SARGISON, 2007). Within this context, current studies on crude glycerin (CG) are noteworthy because of its high glycerol content and energy potential, because glycerol acts as an important glucose precursor (CHUNG et al., 2007; OSBORNE et al., 2009; RICO et al., 2012; BOYD et al., 2013). Thus, understanding the components that affect animal development, and consequently, the livestock system's production and profitability, is of importance. The goal of this study was to evaluate the effects of providing water supplemented with crude $C G$ to ewes during pregnancy and at the onset of lactation on the weight and body measurements of their offspring from birth until weaning.

\section{Materials and Methods}

The experiment was conducted in 2014 at the Professor Hélio Barbosa Experimental Farm, Igarapé, MG, Brazil. The animals were used in accordance with the protocol approved by the Animal Experimentation Ethics Committee (CEUA, protocol 056/11).

Twenty-four pregnant ewes between 3- and 4-years-old, with a single fetus (Lacaune $\mathrm{x}$ East Friesian genotype) and a mean weight of $66.14 \pm$ $6.23 \mathrm{~kg}$ were used. The ewes were distributed in a completely randomized design, allocated into four different treatments in respect to CG supplement ( 0 , $1.5,3.0$, and $4.5 \%$ dry matter $[\mathrm{DM}])$.

The chemical composition of $\mathrm{CG}$ is shown in Table 1. The rations (Table 2) were formulated to meet the nutritional demand for each category (pregnancy or lactation), according to that established by the NRC (2007). CG was added to water and adjusted in relation to the ewes' total dry matter intake and water consumption, where the supplement was recalculated every four days 
according to the mean amount of feed leftover by the ewes during this period. The feed was divided into two meals (at 0800 and 1600). Water or a mixture of water plus CG was provided once daily at a total volume of $12 \mathrm{~L}$.

The supplement was provided throughout pregnancy and lactation; however, the experimental period was restricted to 70 days of pregnancy until birth and a subsequent 45 days of lactation. From the beginning of the 70 days of pregnancy, live weight and body condition scores (BCS) were recorded every two weeks. For the latter, a scale from one to five was used according to the NRC (2007), where a score of one corresponded to a very lean animal and a score of five to an obese animal. Weighing was performed in the morning before the first daily feeding.
Table 1. Chemical composition and energy content of the crude glycerin.

\begin{tabular}{lc}
\hline Nutrient $^{*}$ & Nutrient $\%$ \\
\hline Dry matter & 85.40 \\
Crude protein & 0.06 \\
Glycerol & 80.70 \\
Ether extract & 13.41 \\
Mineral matter & 5.71 \\
NDF & - \\
ADF & - \\
TCH & 75.00 \\
NFC & 75.00 \\
Density $(\mathrm{g} / \mathrm{mL})$ & 1.20 \\
Energy $(\mathrm{kcal} / \mathrm{kg})$ & $3,954.00$ \\
\hline
\end{tabular}

*Values expressed based on dry matter. NDF = neutral detergent fiber, $\mathrm{ADF}=$ acid detergent fiber, $\mathrm{TCH}=$ total carbohydrates, $\mathrm{NFC}=$ non-fiber carbohydrates.

Table 2. Percentage and chemical composition of the rations offered to the ewes during pregnancy and lactation.

\begin{tabular}{lccc}
\hline Ingredient $^{*}(\%)$ & 0 to 120 days pregnancy & 120 to 145 days pregnancy & Lactation \\
\hline Tifton hay & 60.27 & 52.39 & 50.33 \\
Cornmeal & 36.08 & 41.02 & 31.51 \\
Soybean meal & 2.12 & 5.00 & 16.21 \\
Sheep salt & 1.00 & 1.00 & 1.00 \\
Common salt & 0.50 & 0.50 & 0.50 \\
Limestone & 0.017 & 0.182 & 0.346 \\
Dicalcium Phosphate & 0.005 & 0.005 & 0.095 \\
\hline Nutrient ${ }^{*}$ ) & & & 89.56 \\
\hline Dry matter & 89.02 & 89.03 & 15.57 \\
Crude protein & 10.00 & 14.24 & 42.00 \\
NDF & 47.56 & 42.68 & 21.00 \\
ADF & 23.35 & 21.00 & 0.43 \\
Calcium & 0.31 & 0.48 & 0.37 \\
Phosphorus & 0.24 & 0.29 & 69.53 \\
\hline TDN & 67.43 & 69.63 & \\
\hline
\end{tabular}

*Values expressed based on dry matter. $\mathrm{NDF}=$ neutral detergent fiber, $\mathrm{ADF}=$ acid detergent fiber, $\mathrm{TDN}=$ total digestible nutrients.

After lambing, the ewes accompanied their lambs (11 females and 13 males) for approximately six weeks (45 days). The ewes and their offspring remained together in individual stalls during the first 10 days post-lambing, during which time they were clinically examined and weighed.
Next, the controlled nursing management system was adopted, in which the lambs spent the night with their respective ewes and were removed the following day and allocated into separate stalls.

Beginning at birth, lamb body weight was monitored daily throughout the 45 days (nursing 
period). Lamb biometrics were evaluated every two weeks from birth until weaning, using a measuring tape and hipometer. Measurements were always taken in the afternoon and with the animal standing. The following measurements were evaluated: wither height (WH, distance from the highest point of the cranial border of the scapula to the ground); body length (BL, distance from the cranial border of the scapula to the greater tuberosity of the femur); thoracic circumference (TC, circumference of the thorax immediately posterior to the scapulas); chest width $(\mathrm{CW}$, distance between the cranial border of the scapulas); shank length (SL, distance from the greater trochanter to the edge of the femorotibial joint); and shank width (SC, measurement taken around the medial portion of the leg, above the femorotibial joint).

Multiple regression, as a function of all the following covariates, was performed to evaluate the effect of providing ewes with water supplemented with CG. The covariates were lamb birth weight; dry matter intake throughout pregnancy (kg); $\mathrm{BCS}$ at insemination, mid-pregnancy, and end of pregnancy (linear and quadratic effects); ewe live weight (ELW) at insemination, mid-pregnancy, and end of pregnancy (linear and quadratic effects); CG content (linear, quadratic, and cubic effects); and lamb sex (male or female, 1 and 0 , respectively). Covariates were selected using the stepwise procedure. Scenarios were simulated using the model obtained with all possible combinations of values of the independent variables selected, within the following ranges: $\mathrm{CG}, 0$ to $6 \%$, in $0.2 \%$ intervals; lamb sex, male or female; BCS, 1 to 5 , in 0.1 intervals; and ELW from 40 to $90 \mathrm{~kg}$, in 1.3 $\mathrm{kg}$ intervals. Simulations were run for 108,000 iterations. Based on the model's predicted birth weights, combinations of values for the variables were separated into quartiles based on the results obtained, thus allowing us to identify which combinations yielded lighter, intermediate, and heavier lambs at birth.

The biometrics measured were analyzed by fitting mixed linear models, in which the parameters were estimated using restricted maximum likelihood, where the effect of glycerin supplementation and phases (days in relation to lambing) were allocated as fixed effects and the lambs were allocated as a random effect in the model. The need to include functions to model any heteroscedasticity between glycerin levels for each variable was evaluated using the fitted Akaike's criterion (AIC). Autoregressive correlation structures were also used to detect error dependency between phases.

The statistical analyses were conducted in $\mathrm{R}$ (R CORE TEAM, 2014). The mixed models were fitted using the nlme package (PINHEIRO et al., 2013), whereas the graphs were generated using the ggplot2 package (WICKHAM, 2009).

\section{Results and Discussion}

The model selected to evaluate the effects of providing water supplemented with $\mathrm{CG}$ to ewes was comprised of the four following variables: $\mathrm{CG}$, crude glycerin content (\%) in supplemented water provided to the ewes; lamb SEX (1 for male and 0 for female); BCS, corresponding to the body condition score (1 to 5, where 1 are lean and 5 are obese animals) of the ewes during the final trimester of pregnancy; and ELW, representing ewe live weight at lambing in $\mathrm{kg}$ :

$$
L W=3.1+0.64 C G-0.11 C G^{2}+0.67 S E X-0.07 B C S^{2}+0.0003 E L W^{2}
$$

CG content explained $5.2 \%$ of the variation observed $\left(\omega 2\right.$, partial $\left.r^{2}\right)$, accompanied by BCS $\omega 2=12.3 \%$, SEX $\omega 2=19.2 \%$, and ELW $\omega 2 \mathrm{~m}=$
$26.5 \% ; r^{2}=63 \%$. The distribution of the results predicted by the model presented in Figure 1 indicated that lighter lambs, in which lamb weight 
(LW) was lower than $3.98 \mathrm{~kg}$, were the result of the combination of ewe weight (between 40 and $50 \mathrm{~kg}$, approximately 7.80 to $9.95 \%$ of the EWL), $\mathrm{CG}$ supplementation at high or low levels (i.e., a quadratic response), and BCS of ewes (4 and 5). The combination of these factors warn of increased mortality at birth, considering that Nóbrega Júnior et al. (2005) emphasized that inadequate ewe nutrition during the last trimester of pregnancy leads to a shortened pregnancy and reduced lamb weight and vigor at birth. The combination also results in low energy reserves for neonates, and consequently, a metabolism that is less adapted to produce heat in response to the environment. Thus, the time that lambs remain standing to perform their first feeding is increased, making them more susceptible to the hypothermia/starvation complex, and consequently, may lead to death.

In contrast, heavier lambs, with LW greater than $5.5 \mathrm{~kg}$, obtained in the simulation, were born from heavy ewes, between 80 and $90 \mathrm{~kg}$ (approximately 6.11 to $6.88 \%$ of EWL), that received between $2 \%$ and $4 \% \mathrm{CG}$, and had low BCSs. In this combination, the intermediate CG levels appear to be ideal in combination with the other factors described in the model, such as weight, BCS, and sex. Adequate nutrition is essential to maximize colostrum production and immunoglobulin concentration, and to overcome the hypothermia/ starvation complex, ensuring offspring survival and the profitability of the livestock system (AWEMUA et al., 1999).

Several studies have suggested body score evaluation it is a precise and practical method to evaluate nutritional status in sheep (GUNN et al., 1984; RIBEIRO et al., 2003). Ewes with low weight at lambing (score of 1-2.5) could produce less colostrum or lambs could have an altered ability to ingest or absorb the colostrum immunoglobulins (CHRISTLEY et al., 2003). This study demonstrated that both ewe BCS and ELW affect lamb birth weight. However, we also demonstrated that small and heavy ewes, and those that had a high BCS, birthed light lambs, which implies that high energy intake in ewes limited muscle growth capacity, causing the lambs to be malnourished or have stunted growth during postnatal life (GREENWOOD et al., 2002; KENYON et al., 2006; BELL, 2006).

Ducker and Boyd (1977) focused on ewe weight combined with body score. When ewes had similar weights, but were small with a high body score, they exhibited a higher ovulation rate than large ewes with a lower score. Gunn et al. (1984) recommend a body score of 2.5 at insemination, suggesting that it is the minimum to attain acceptable ovulation rates.

Therefore, lamb survival is correlated to nongenetic factors, such as lamb sex, double births, ewe age, season, birth year, and birth weight (MORRIS et al., 2000; MANDAL et al., 2007; BINABAJ et al., 2013). Lamb sex had the largest impact on birth weight, representing $27.5 \%$ of the variation found in this study; males weighed more than the females. Idris et al. (2010) reported that female lambs are born having lower weight than males; however, the higher value did not affect growth rates through weaning. 
Figure 1. Frequency of the values assumed by the predictor variables (glycerin content, live weight, ewe body condition score, and lamb sex) and their respective predicted weights according to the fitted multiple regression model. Grayscale shading, from darkest to lightest, corresponds to the separation of the predicted birth weights into four symmetric categories: $\mathrm{LW} \leq 3.98,3.98<\mathrm{LW} \leq 4.72,4.72<\mathrm{LW} \leq 5.46, \mathrm{LW}>5.46$.
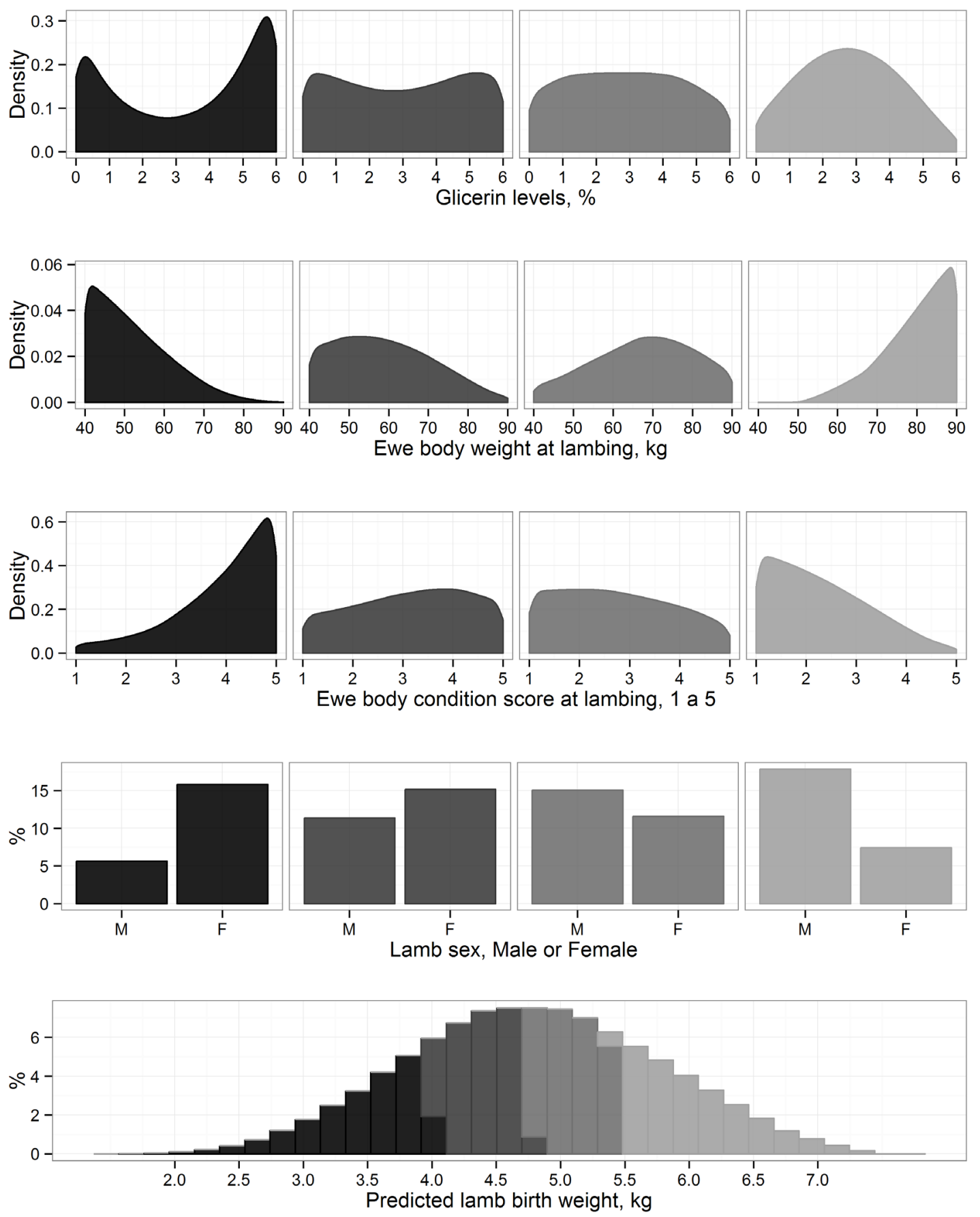

The ideal range for birth weight was from 3.5 in the present study. Simulated lamb birth weight to $5.5 \mathrm{~kg}$ in the New Zealand herds, as repor ted by from 3.98 to $5.5 \mathrm{~kg}$ was achieved in sheep fed Dalton et al. (1980), and this corroborates results between 2.0 and $4.0 \%$ CG, weighing between 60 
and $70 \mathrm{~kg}$, with a BCS between 2 and 4 . However, attention should be given to selecting the matrixes, which should be done in order to achieve maximum birth weight. Birth viability should be considered, because dystocia is one of the causes of mortality in birthing heavier lambs (SAWALHA et al., 2007).

The biometric results showed that providing water supplemented with CG to the ewes did not promote differences in weight from birth through weaning, and there was no significant effect for lamb sex during this period (Table 3). The biometric data reflect breed characteristics, and when development occurs under similar environmental conditions, there is little variation (AFOLAYAN et al., 2006). This was likely the cause of the lack of differences detected in this study. Fajemilehin and Salako (2008) determined the thoracic circumference measurement best correlated with weight, both at birth and at weaning. However, in the present study, there was no effect of the treatments on this measurement.

Table 3. Means and standard errors of body length (BL), wither height (WH), thoracic circumference (TC), chest width (CW), shank width (SW), and shank length (SL) in centimeters from lamb birth (day 1) until weaning (day 45).

\begin{tabular}{cccccccc}
\hline & CG & BL & WH & TC & CW & SW & SL \\
\hline \multirow{2}{*}{ DAY } & $0.0 \%$ & $33.46(1.13)$ & $39.75(1.19)$ & $39.54(1.74)$ & $10.35(0.87)$ & $13.82(1.01)$ & $19.64(0.97)$ \\
1 & $1.5 \%$ & $32.91(1.16)$ & $40.24(0.87)$ & $39.51(1.92)$ & $10.40(0.86)$ & $13.42(1.00)$ & $18.35(0.97)$ \\
& $3.0 \%$ & $34.47(1.90)$ & $43.32(0.86)$ & $40.13(2.51)$ & $10.70(0.91)$ & $13.99(1.05)$ & $19.96(1.02)$ \\
& $4.5 \%$ & $32.775(1.44)$ & $39.74(0.87)$ & $38.79(2.46)$ & $10.46(0.99)$ & $14.87(1.14)$ & $18.57(1.11)$ \\
\hline & $0.0 \%$ & $41.67(1.19)$ & $46.27(1.26)$ & $48.24(1.81)$ & $14.14(0.91)$ & $17.13(1.06)$ & $24.52(1.04)$ \\
DAY & $1.5 \%$ & $38.53(1.29)$ & $45.28(0.95)$ & $46.32(2.08)$ & $13.45(0.95)$ & $16.77(1.11)$ & $22.84(1.10)$ \\
15 & $3.0 \%$ & $39.68(2.23)$ & $46.44(0.97)$ & $46.47(2.76)$ & $14.09(1.02)$ & $17.07(1.20)$ & $22.29(1.19)$ \\
& $4.5 \%$ & $40.78(1.71)$ & $44.97(0.99)$ & $45.29(2.77)$ & $13.74(1.14)$ & $16.65(1.33)$ & $24.29(1.34)$ \\
\hline \multirow{5}{*}{ DAY } & $0.0 \%$ & $45.49(1.18)$ & $49.34(1.26)$ & $56.87(1.80)$ & $15.78(0.91)$ & $19.66(1.05)$ & $26.01(1.03)$ \\
30 & $1.5 \%$ & $41.78(1.16)$ & $49.36(0.87)$ & $55.71(1.92)$ & $16.41(0.86)$ & $17.63(1.00)$ & $25.10(0.97)$ \\
& $3.0 \%$ & $43.61(1.90)$ & $49.46(0.86)$ & $57.39(2.51)$ & $15.90(0.91)$ & $18.40(1.05)$ & $26.38(1.02)$ \\
& $4.5 \%$ & $46.70(1.56)$ & $49.18(0.93)$ & $54.80(2.63)$ & $15.40(1.06)$ & $18.27(1.24)$ & $27.02(1.21)$ \\
\hline \multirow{5}{*}{ DAY } & $0.0 \%$ & $49.35(1.18)$ & $54.06(1.26)$ & $61.30(1.82)$ & $17.94(0.92)$ & $20.10(1.07)$ & $31.43(1.03)$ \\
45 & $1.5 \%$ & $47.28(1.16)$ & $53.61(0.87)$ & $59.82(1.93)$ & $17.59(0.87)$ & $20.48(1.01)$ & $30.48(0.97)$ \\
& $3.0 \%$ & $48.90(1.90)$ & $55.74(0.86)$ & $62.87(2.52)$ & $17.29(0.91)$ & $21.51(1.06)$ & $30.53(1.02)$ \\
& $4.5 \%$ & $48.90(1.56)$ & $51.98(0.93)$ & $61.01(2.67)$ & $17.67(1.08)$ & $20.17(1.25)$ & $33.22(1.21)$ \\
\hline & DAY (D) & 0 & 0 & 0 & 0 & 0 & 0 \\
Pr>F & CG & 0.607 & 0.217 & 0.917 & 0.994 & 0.936 & 0.5 \\
& DxCG & 0.652 & 0.329 & 0.994 & 0.997 & 0.885 & 0.694 \\
& SEX & 0.52 & 0.625 & 0.568 & 0.457 & 0.115 & 0.499 \\
\hline
\end{tabular}

\section{Conclusions}

Providing water supplemented with $\mathrm{CG}$ to pregnant ewes does not alter body measurements of the lambs. Ewes with a larger body size and moderate scores birthed heavier lambs. Providing water supplemented with $2 \%$ to $4 \%$ CG to pregnant ewes increases lamb birth weight. 


\section{References}

AFOLAYAN, R. A.; ADEYINKA, I. A.; CAM LAKPINI, E. A estimativa do peso vivo de medidas corporais em Yankasa ovelhas. Czech Journal of Animal Science, Champaign, v. 51, n. 1, p. 343-348, 2006.

AWEMUA, E. M.; NWAKALORA, L. N.; ABUBAKAR, B. Y. Environmental influences on pre-weaning mortality and reproductive performance of Red Sokoto does. Small Ruminant Research, Amsterdam, v. 34, n. 2, p. 161-165, 1999.

BELL, A. W. Prenatal programming of postnatal productivity and health of livestock: a brief review. Australian Journal of Experimental Agriculture, Ithaca, v. 46, n. 6, p. 725-732, 2006.

BINABAJ, F. B.; TAHMOORESPUR, M.; ASLAMINEJAD, A. A.; VATANKHAH, M. The investigation of non-genetic factors affecting survival of Karakul lambs from birth to one year of age using linear and nonlinear models. Small Ruminant Research, Amsterdam, v. 113, n. 1, p. 34-39, 2013.

BOYD, J.; BERNARD, J. K.; WEST, J. W. Effects of feeding different amounts of supplemental glycerol on ruminal environment and digestibility of lactating dairy cows. Journal of Dairy Science, Georgia, v. 96, n. 1, p. 470-476, 2013.

BRADFORD, G. E. The role of maternal effects in animal breeding. VII. Maternal effects in sheep. Journal of Animal Science, Champaign, v. 35, n. 6, p. 1324-1334, 1972.

CHRISTLEY, R. M.; MORGAN, K. L.; PARKIN, T. D. H.; FRENCH, N. P. Factors related to the risk of neonatal mortality, birth-weight and serum immunoglobulin concentration in lambs in the UK. Preventive Veterinary Medicine, Glasgow, v. 57, n. 4, p. 209-226, 2003.

CHUNG, Y. H.; RICO, D. E.; MARTINEZ, C. M.; CASSIDY, T. W.; NOIROT, N.; AMES, A.; VARGA, G. A. Effects of feeding dry glycerin to early postpartum Holstein dairy cows on lactational performance and metabolic profiles. Journal of Dairy Science, Pennsylvania, v. 90, n. 12, p. 5682-5691, 2007.

DALTON, D. C.; KNIGHT, T. W.; JOHNSON, D. L. Lamb survival in sheep breeds on New Zealand hill country. New Zealand Journal of Agricultural Research, Hamilton, v. 39, n. 2, p. 53-62, 1980.

DUCKER, M. J.; BOYD, J. S. The effect of body size and body condition on the ovulation rate of ewes. Animal Production, Glasgow, v. 24, n. 3, p. 377-385, 1977.
ELTAWIL, E. A.; HAZEL, L. N.; SIDWELL, G. M. Evaluation of environmental factors affecting birth, weaning and yearling traits in navajo sheep. Journal of Animal Science, Champaign, v. 31, n. 5, p. 823-827, 1970.

FAJEMILEHIN, O. K. S.; SALAKO, A. E. Body measurement characteristics of the West African Dwarf (WAD) Goat in deciduous forest zone of Southwestern Nigeria. African Journal of Biotechnology, Ekiti, v. 7, n. 14, p. 2521-2526, 2008.

GAMA, L. T.; DICKERSON, G. E.; YOUNG, L. D.; LEYMASTER, K. A. Effects of breed, heterosis, age of dam, litter size, and birth weight on lamb mortality. Journal of Animal Science, Champaign, v. 69, n. 7, p. 2727-2743, 1991.

GREENWOOD, P. L.; HUNT, A. S.; SLEPETIS, R. M.; FINNERTY, K. D.; ALSTON, C.; BEERMANN, D. H.; BELL, A. W. Effects of birth weight and postnatal nutrition on neonatal sheep: III. Regulation of energy metabolism. Journal of Animal Science, Champaign, v. 80 , n. 1, p. 2850-2861, 2002.

GUNN, R. G.; DONEY, J. M.; SMITH, W. F. The effect of level of pre-mating nutrition on ovulatory rate in Scottish blackface ewes in different body conditions at mating. Animal Production, Bush, v. 39, n. 2, p. 235-239, 1984.

IDRIS, A. O.; KIJORA, C.; EL-HAG, F. M.; SALIH, A. M. Effects of supplementation on late pregnancy and early lactation of body weight of desert ewes and their lambs. Livestock Research for Rural Development, Berlin, v. 22, n. 10, Article \#193, 2010. Available at: <http://www.lrrd. org/lrrd22/10/idri22193.htm>. Accessed at: 10 jan. 2015.

KENYON, P. R.; REVELL, D. K.; MORRIS, S. T. Midpregnancy shearing can increase birthweight and survival to weaning of multiple-born lambs under commercial conditions. Australian Journal of Experimental Agriculture, Palmerston, v. 46, n. 6, p. 821-825, 2006.

MANDAL, A.; PRASAD, H.; KUMAR, A.; ROY, R.; SHARMA, N. Factors associated with lamb mortalities in Muzaffarnagari sheep. Small Ruminant Research, Amsterdam, v. 71, n. 1, p. 273-279, 2007.

MANDAL, A.; ROY, R.; ROUT, P. K. Direct and maternal effects for body measurements at birth and weaning in Muzaffarnagari sheep of India. Small Ruminant Research, Amsterdam, v. 75, n. 2, p. 123-127, 2008.

MORRIS, C. A.; HICKEY, S. M.; CLARKE, J. N. Mukasa-Mugerwa, E. Genetic and environmental factors affecting lamb survival at birth and through to weaning. New Zealand Journal of Agricultural Research, Hamilton, v. 43, n. 4, p. 515-524, 2000. 
NATIONAL RESEARCH COUCIL - NRC. Nutrient requirements of small ruminants. $7^{\text {th }}$ ed. Washington: National Academic Press, 2007. 408 p.

NÓBREGAJÚNIOR, J. E.; CORREA, F. R.; NÓBREGA, R. S.; MEDEIROS, J. M.; VASCONCELOS, J. S.; SIMÕES, S. V. D.; TABOSA, I. M. Mortalidade perinatal de cordeiros no semiárido da Paraíba. Pesquisa Veterinária Brasileira, Seropédica, v. 25, n. 4, p. 171178, abr./jun. 2005.

OSBORNE, V. R.; ODONGO, N. E.; CANT, J. P.; SWANSON, K. C.; MCBRIDE, B. W. Effects of supplementing glycerol and soybean oil in drinking water on feed and water intake, energy balance, and production performance of per parturient dairy cows. Journal of Dairy Science, Ontario, v. 92, n. 2, p. 698$707,2009$.

PINHEIRO, J.; BATES, D.; DEBROY, S.; SARKAR, D. $R$ Development Core Team \& nlme: linear and nonlinear mixed effects models: R Package Version, 3.1- 110. Software. Foundation for Statistical Computing, Vienna, Austria, 2013. Conjunto de programas. CD-ROM.
R CORE TEAM. R: a language and environment for statistical computing. Vienna: R Foundation for Statistical Computing, 2014. Available at: <http://www.R-project. org/2014>. Accessed at: 10 jan. 2015.

RIBEIRO, L. A. O.; FONTANA, C. S.; WALD, V. B. Relação entre a condição corporal e a idade das ovelhas encarneiradas com a prenhez. Ciência Rural, Santa Maria, v. 33, n. 2, p. 357-361, 2003.

RICO, D. E.; CHUNG, Y. H.; MARTINEZ, C. M. Effects of partially replacing dietary starch with dry glycerol in a lactating cow diet on ruminal fermentation during continuous culture. Journal of Dairy Science, Park, v. 95, n. 6, p. 3310-3317, 2012.

SARGISON, N. D. Pregnancy toxaemia. In: AITKEN, I. D. Diseases of sheep. $4^{\text {th }}$ ed. Oxford: Blackwell Publishing, 2007. p. 359-363.

SAWALHA, R. M.; CONINGTON, J.; BROTHERSTONE, S.; VILLANUEVA, B. Analysis of lamb survival of Scottish Black face sheep. Animal, Edinburgh, v. 1, n. 1, p. 151-157, 2007.

WICKHAM, H. ggplot2: elegant graphics for data analysis. Software. New York: Springer, 2009. Conjunto de programas. CD-ROM. 
